\title{
Impact of microtopography on the geochemistry of soils within archaeological sites in SE Poland
}

\author{
Wojciech Zgłobicki
}

Received: 29 October 2012/ Accepted: 28 February 2013/Published online: 17 March 2013

(C) The Author(s) 2013. This article is published with open access at Springerlink.com

\begin{abstract}
The geochemical record of human impact within three archaeological sites in SE Poland was analysed. The total levels of $\mathrm{Cd}, \mathrm{Cu}, \mathrm{Pb}, \mathrm{Zn}$ and $\mathrm{P}$ were defined. The content of the studied elements was found to be higher than the determined geochemical background. In all cases, significantly higher concentrations (2-3 times) of trace metals were found in sediments filling small depressions and foot-slope locations. These concentrations were often higher than in the profiles within the archaeological objects. The vertical distributions of elements were also different from soil profiles located on flat surfaces. The study thus confirms that microtopography and soil erosion may impact (diversify) the initial horizontal and vertical variation of geochemistry of soils within archaeological sites caused by human activity. This should be taken into account when using geochemical prospecting in archaeological studies in areas with varied topography.
\end{abstract}

Keywords Geochemical prospecting - Microtopography · Phosphorus · Trace metals · SE Poland

\section{Introduction}

Geochemical prospecting is a noninvasive method of detecting and surveying archaeological sites and features. Generally, it is based on the assumption that human

W. Zgłobicki ( $\square)$

Department of Geology and Lithosphere Conservation,

Maria Curie-Sklodowska University, Krasnicka 2cd,

20-718 Lublin, Poland

e-mail: zglobek@hektor.umcs.lublin.pl settlement and activities are reflected in the geochemical record (Lambert 1998; Oonk et al. 2009). The most frequently used elements in such studies are $\mathrm{P}, \mathrm{Ca}, \mathrm{K}, \mathrm{Na}$ and $\mathrm{Mg}$ as well as trace metals such as $\mathrm{Cd}, \mathrm{Cr}, \mathrm{Cu}, \mathrm{Pb}$ and $\mathrm{Zn}$ (Lutz 1951; Aston et al. 1998; Schlezinger and Howes 2000; Wells et al. 2000; Terry et al. 2004; Oonk et al. 2009; Cabala et al. 2012; Tian et al. 2012). Most of the studies were primarily concerned with the horizontal variation in the content of the studied elements within the archaeological sites (Entwisle et al. 2000; Parnell et al. 2002).

Microtopography and geomorphological processes (mainly soil erosion) can impact the quality of the geochemical record of human activity (Wells et al. 2000; Terry et al. 2004; Szwarczewski 2005; Zgłobicki and Rodzik 2007). In the case of archaeological sites located in areas with varied topography, the original distribution of elements can be disrupted as a result of erosion occurring after the elements were introduced into the soil. Erosion caused by water, wind and tillage moves the soil and elements downslope. Eroded material is accumulated within depressions and at the foot of slopes as colluvia. As such, microtopography and erosion provides yet another challenge for using geochemical prospection in archaeology, alongside the problems indicated by Oonk et al. (2009) such as the lack of a unified methodological approach, an accurate determination of the geochemical background, and a thorough understanding of the natural geochemical processes occurring in archaeological sites. This study attempts to assess the impact of microtopography on the distribution of $\mathrm{Cd}, \mathrm{Cu}, \mathrm{P}, \mathrm{Pb}$ and $\mathrm{Zn}$ content in the soil and colluvial profiles obtained within three archaeological sites in SE Poland. The selection of elements resulted from their common use in geochemical studies at archaeological sites (Aston et al. 1998; Schlezinger and Howes 2000; Oonk et al. 2009). 


\section{Methods}

The study was conducted on three archaeological sites located in SE Poland (Fig. 1). Eight continuous profiles were analysed (to the depth of $100 \mathrm{~cm}$ ). For each site, reference profiles were also sampled (to the depth of $30 \mathrm{~cm}$ ) from places with similar environment characteristics, but located outside the boundaries of archaeological sites. In total, data for 89 samples were obtained.

The samples were collected with the use of an Eijkelkamp sampler with a diameter of about $3 \mathrm{~cm}$. After collection, the cores were divided into $10-\mathrm{cm}$ sections. The general content of $\mathrm{Cd}, \mathrm{Cu}, \mathrm{P}, \mathrm{Pb}$ and $\mathrm{Zn}$ was examined. Basic physical and chemical parameters of the samples were also determined (grain size distribution, organic matter content, $\mathrm{pH}$ ). The mineralisation of the samples was carried out with the use of aqua regia, according to the ISO $11466 / 2002$ standard. Zinc, cadmium, copper and lead levels were determined using the atomic absorption spectroscopy method, while total phosphorus was determined spectrophotometrically using the ascorbic acid method (Analytical Laboratory, Faculty of Chemistry; Department of Soil Science, Faculty of Earth Sciences and Spatial Management). The content of the analysed elements was determined in the $<1 \mathrm{~mm}$ fraction.

The spectrometer had the following limits of detectability: Cd, $0.006 \mathrm{mg} / \mathrm{k}$; $\mathrm{Cu}, 0.03 \mathrm{mg} / \mathrm{kg} ; \mathrm{Pb}, 0.1 \mathrm{mg} / \mathrm{kg}$; $\mathrm{Zn}, 0.008 \mathrm{mg} / \mathrm{kg}$. Converted into the minimum detectable content (enabled by the method used) in a sample, the

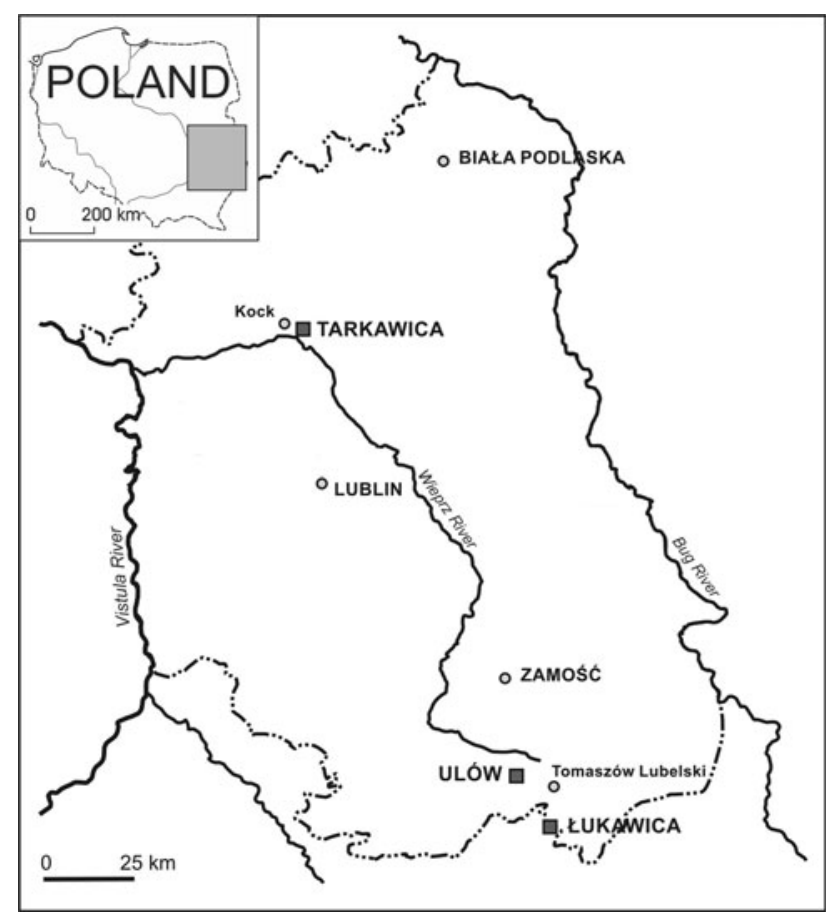

Fig. 1 Location of the studied sites values are as follows: $\mathrm{Cd}, 0.2 \mathrm{mg} / \mathrm{kg} ; \mathrm{Cu}, 1.25 \mathrm{mg} / \mathrm{kg} ; \mathrm{Pb}$, $4.1 \mathrm{mg} / \mathrm{kg} ; \mathrm{Zn}, 0.3 \mathrm{mg} / \mathrm{kg}$. The method used for the determination of trace metals was tested based on certified reference material (Table 1). In the case of phosphorus, the detection limit of spectrophotometer was $0.005 \mathrm{mg} / \mathrm{l}$.

Study area

The archaeological sites under study are located in areas with varied landforms, usually on culminations and slopes of small hills. The microtopography within the sites was also varied and featured small depressions (0.5-1.5 m deep). Two distinct, types of representative soil profiles were analysed: (a) located at plateau tops (flat areas), (b) located at bottoms of depressions and foot-slopes.

The study encompassed sites associated with various cultures and characterised by a varying duration of human settlement. Within the Łukawica site, traces of settlements were found and dated to the Mesolithic and Neolithic periods, Bronze Age, Roman Period and the Migration Period; an early mediaeval settlement occupying an entire promontory covered an area of 1.6 ha. The multicultural settlement at Tarkawica was used in the Early Bronze Age, Early Iron Age and the Roman Period. Most of the 101 features were associated with the Przeworsk culture settlement in the Roman Period and date back to the late second and first half of the third century AD (Kłosińska and Juściński 2001). In Ulów, a complex of sites was discovered and dated to the late Roman Period and early phase of the Migration Period. They include two burial grounds and two settlements (Niezabitowska 2005).

Łukawica (L-1, L-2, L-4) - the site is located within a tip of a meander of the Łukawica River. Nowadays, the area is used for agricultural purposes (mainly as arable land). The L-1 profile is located at the probable site of a residential building from the Roman Period. The profile has the following structure: (a) $0-15 \mathrm{~cm}$, the arable humus horizon (brown and grey, silty sand); (b) 15-35 cm, cultural horizon, black (silty sand); (c) 35-70 cm, grey and brown sand horizon; (d) 70-100 cm, parent material (yellow and grey sand). In L-2, the following horizons are distinguished: (a) $0-20 \mathrm{~cm}$, the arable humus horizon (cultural, silty sand); (b) 20-40 cm, transitional horizon (A/ $\mathrm{B}_{\mathrm{v}}$, silty sand); (c) 40-55 cm, browning horizon $\left(\mathrm{B}_{\mathrm{br}}\right)$; (d) 55-100 cm, parent material (C, sand). Profile L-4 is different as it is composed of sandy colluvia filling a small depression (0.5 $\mathrm{m}$ deep): (a) 0-20 cm, the arable humus horizon $\left(\mathrm{A}_{\mathrm{p}}\right)$; (b) $20-50 \mathrm{~cm}$, brown and grey colluvia; (c) 50-100 cm, brown colluvia.

Tarkawica (Tk-1, Tk-4)—the archaeological site is located on a sand dune in the valley of the Wieprz River, east of the town of Kock. Profile Tk-1 is located within the culmination (at the probable site of residential building 
Table 1 Certified and measured content of trace metals in certified reference material SAN JOAGUIN SOIL CRM 2709

\begin{tabular}{llllr}
\hline Element & $\mathrm{Cd}$ & $\mathrm{Cu}$ & $\mathrm{Pb}$ & \\
\hline Certified content $(\mathrm{mg} / \mathrm{kg})$ & $0.38 \pm 0.11$ & $34.6 \pm 0.7$ & $18.9 \pm 0.5$ & $\mathrm{Zn}$ \\
Measured content $(\mathrm{mg} / \mathrm{kg})$ & $0.32 \pm 0.12$ & $27.8 \pm 0.9$ & $17.3 \pm 0.7$ & $86.1 \pm 4.0$ \\
\hline
\end{tabular}

from the Przeworsk culture), while profile Tk-4 at the foot of a 4- to 5-m-high dune. Currently the dune is used for agricultural purposes. Profile Tk-1 has the following structure (rusty soil): (a) 0-20 cm, the grey and brown arable humus horizon $\left(A_{p}\right)$; (b) 20-30 cm, transitional horizon $\mathrm{A} / \mathrm{B}_{\mathrm{v}}$, (rusty and grey); (c) $30-80 \mathrm{~cm}$, browning horizon $\left(\mathrm{B}_{\mathrm{v}}\right)$; (d) 80-100 cm, parent material $\mathrm{C}$ (yellow and grey sand). Profile Tk-4 contains the following horizons: (a) 0-30, the arable humus horizon (grey and brown); (b) $30-55 \mathrm{~cm}$, black colluvia silty sand; (c) $55-70 \mathrm{~cm}$, eluvial horizon (light-grey sand); (d) $70-100 \mathrm{~cm}$, illuvial horizon (rusty sand).

Ulów (U-1, U-3, U-5) — the complex of sites in Ulów (Tomaszów Roztocze) is located on a plateau top and slopes of a dry erosion-denudation valley. At present, a pine forest grows in the area. Profile U-1 is located in the western part of a burial ground on the plateau top. In the top part of the profile, there is a grey and brown cultural horizon $(0-26 \mathrm{~cm})$. The essential part of the profile is composed of rusty and brown sand $(26-70 \mathrm{~cm}$ : browning horizon $\mathrm{B}_{\mathrm{v}}$ ), below which, at the depth of $70 \mathrm{~cm}$, lies the parent rock (straw-coloured sand). Profile U-3 lies about $100 \mathrm{~m}$ further to the south (on the plateau top), within a rectangular structure surrounded with a low earthwork that was part of a late Roman settlement (preliminary archaeological dating). The profile structure clearly indicates human influence: the upper part consists of massive darkgrey silty sand $(0-25 \mathrm{~cm})$; below $(25-45 \mathrm{~cm})$, there is dark brown silty sand with light-brown inter-bedding; the underlying horizon $(45-70 \mathrm{~cm})$ is light-brown with darker inserts; and the bottom part of the profile consists of lightgrey sand (parent material). Profile U-5 is located nearby, at the bottom of a small trough (about $1 \mathrm{~m}$ deep) dissecting the plateau top. It is composed of sandy colluvia, massive and dark grey in the upper part $(0-35 \mathrm{~cm})$; grey with lighter inter-bedding below; and rusty with lighter and darker layers in the bottom part of the profile $(65-100 \mathrm{~cm})$.

\section{Results}

The natural characteristics of studied soil profiles are not conducive to the retention of elements delivered to the land surface. This results from a low content of the clay fraction and organic matter, and an acidic $\mathrm{pH}$ of the soils. The soils and sediments under study have an acidic $\mathrm{pH}$ of 3-5 and low content of organic matter that is above $2 \%$ only in the surface layers (Table 2). Although differences occur between the analysed profiles, generally the sorption determinants of the analysed elements are similar. The most varied parameter is the organic matter content: it is clearly higher in the upper parts of the profiles, which is conducive to the binding of metals and phosphorus.

The determined levels of the studied elements are not high in comparison with the values provided for the region by Lis and Pasieczna (1995) and Zgłobicki et al. (2011), particularly in the case of copper and zinc. The geochemical background determined for the studied elements was similar for all three sites (Table 3). The smallest differences were found in the case of copper. The geochemical background for the test sites was exceeded in $80 \%$ of the samples. Taking into account the absolute values of trace metal concentrations, they can be arranged in the following order: $\mathrm{Cd}<\mathrm{Cu}<\mathrm{Pb}<\mathrm{Zn}$.

The highest mean trace metal content and the maximum values were found in the case of profile L-4, Tk-4 and U-5, located within depressions or at the foot of a slope. This pattern did not occur in the case of phosphorus (Table 3). The same situation occurred in the case of enrichment ratios: they reached the highest values for profile L-4, Tk-4 and U-5. This was the case both for the enrichment ratios of the particular elements (again, with the exception of phosphorus) and for total ratios (Fig. 2).

Vertical variation differences were found between profiles located in flat areas and within depressions. The differences concerned changes occurring with increasing depth (shape of the curve) and the depth at which maximum concentrations appeared. Profiles located at the bottom of depressions showed a greater vertical variation of element content (Fig. 3).

Phosphorus usually showed correlations with cultural horizons found in the profiles, enriched with organic matter. Phosphorus content values in these horizons were clearly higher (profiles L-2, Tk-4) (Fig. 3). In the case of profile U-1, greater concentrations of phosphorus occurred in the browning horizon (higher clay fraction content).

\section{Discussion}

Within all the profiles, the content of the studied elements exceeded the geochemical background (on average, 3-5 
Table 2 The basic properties of the soil profiles

\begin{tabular}{llllll}
\hline & $\begin{array}{l}\text { Content of } \\
\text { sand (\%) }\end{array}$ & $\begin{array}{l}\text { Content of } \\
\text { loam }(\%)\end{array}$ & $\begin{array}{l}\text { Content } \\
\text { of clay } \\
(\%)\end{array}$ & $\begin{array}{l}\text { Organic } \\
\text { matter } \\
\text { content }(\%)\end{array}$ & $\mathrm{pH}$ \\
\hline L-1 & $64-89$ & $8-30$ & $2-6$ & $0.3-2.8$ & $5.0-5.8$ \\
L-2 & $71-96$ & $2-28$ & $1-6$ & $0.1-2.8$ & $4.8-6.0$ \\
L-4 & $75-89$ & $8-20$ & $3-5$ & $0.5-2.0$ & $3.9-4.7$ \\
Tk-1 & $85-96$ & $3-12$ & $1-3$ & $0.2-1.7$ & $3.6-4.2$ \\
Tk-4 & $62-91$ & $7-33$ & $2-5$ & $0.2-2.2$ & $3.3-6.0$ \\
U-1 & $68-91$ & $7-28$ & $2-6$ & $0.2-2.6$ & $3.1-4.1$ \\
U-3 & $58-75$ & $21-40$ & $4-8$ & $0.3-4.0$ & $3.1-4.1$ \\
U-5 & $59-72$ & $24-37$ & $4-8$ & $0.3-3.0$ & $3.4-4.2$ \\
\hline
\end{tabular}

times). This indicates a direct human impact on the geochemistry of the soils within the archaeological sites. Aston et al. (1998) list five ways of soil enrichment with trace metals as a result of prehistoric human activity: establishment of settlements, breeding of animals in enclosed areas, use of fire (forest burning), ancient metallurgy, handicrafts (leather production, crop processing, etc). According to Schlezinger and Howes (2000), on the other hand, an increase in the phosphorus content in the soil may have resulted from: the deposition of human and animal urine and faeces in the inhabited areas; the accumulation of dead bodies as well as animal and plant remains in the vicinity of settlements; the use of animal dung to fertilise soil.

The spatial distribution of the intensity of geochemical impact varied within the sites studied and, in the case of the profiles analysed, resulted from diverse microtopography and soil erosion processes. Occurrence of depressions and slopes within archaeological sites has changed the initial geochemical record caused by human activity. Within all archaeological sites analysed, markedly higher concentrations of trace metals occur in sediments filling small depressions (Table 3; Figs. 2, 3). This pattern occurs despite the fact that the physical and chemical characteristics of these sediments do not differ from the adjacent areas (Table 2).

Depressions of a natural character (trough-shaped valleys) or anthropogenic character (ditches) constitute a "waste heap" collecting various kinds of mineral and organic material, both through natural processes (erosion and redeposition of soil) and direct human activity. All this resulted in enriching the sediment with the analysed elements, which is most visible in the case of copper and lead (Table 3).

The patterns mentioned above (higher concentrations within depressions) occurred despite of the fact that some profiles sampled on flat surfaces (L-1, Tk-1, U-3) were located within archaeological objects, where high anthropogenic input of elements into the soils occurred. It is advisable to continue the research in order to clarify to what extent microtopography can obliterate the varied geochemical records associated with various forms of human activity within an archaeological site (Entwisle et al. 2000; Parnell et al. 2002).

When a site is located on a plateau top or slope, in places exposed to erosion, there is no geochemical record in the form of increased concentration of the examined elements. Such a situation was found in a case of Tarkawica (Figs. 2, 3). It results from the fact that a layer enriched by trace metals and phosphorus was removed by erosion. In such cases, higher content levels should be expected in colluvia. The record of erosion within the site is manifested in the increased concentration of phosphorus,

Table 3 Basic statistical data concerning element content in the studied profiles

\begin{tabular}{|c|c|c|c|c|c|c|c|c|c|c|c|c|c|c|c|}
\hline & \multicolumn{3}{|l|}{$\mathrm{Cd}$} & \multicolumn{3}{|l|}{$\mathrm{Cu}$} & \multicolumn{3}{|l|}{$\mathrm{P}$} & \multicolumn{3}{|l|}{$\mathrm{Pb}$} & \multicolumn{3}{|l|}{$\mathrm{Zn}$} \\
\hline & A & B & $\mathrm{C}$ & A & B & $\mathrm{C}$ & A & B & $\mathrm{C}$ & A & B & $\mathrm{C}$ & A & B & $\mathrm{C}$ \\
\hline $\mathrm{Bg}$ & 0.3 & & & 1.3 & & & 50 & & & 11.0 & & & 9.0 & & \\
\hline L-1 & 0.4 & 0.4 & 1.6 & 7.5 & 5.7 & 16.7 & 302 & 84 & 395 & 15.9 & 4.8 & 26.7 & 25.2 & 10.4 & 44.8 \\
\hline L-2 & 0.6 & 0.4 & 1.6 & 5.5 & 4.6 & 12.0 & $\underline{307}$ & 265 & 767 & 14.9 & 4.6 & 23.2 & 21.5 & 14.8 & 43.5 \\
\hline L-4 & $\underline{1.8}$ & 0.4 & $\underline{2.3}$ & $\underline{13.2}$ & 3.7 & $\underline{17.5}$ & 193 & 50 & 272 & 34.9 & 12.6 & 57.9 & $\underline{33.8}$ & 13.1 & $\underline{48.5}$ \\
\hline $\mathrm{Bg}$ & 0.1 & & & 1.2 & & & 40 & & & 6.0 & & & 5.0 & & \\
\hline Tk-1 & 0.1 & 0.3 & 0.7 & 1.3 & 0.4 & 2.2 & 167 & 81 & $\underline{283}$ & 9.7 & 3.9 & 17.2 & 11.0 & 4.1 & 17.1 \\
\hline Tk-4 & $\underline{0.3}$ & 0.2 & 0.7 & $\underline{2.3}$ & 1.5 & $\underline{5.2}$ & 137 & 89 & 276 & $\underline{14.4}$ & 5.5 & $\underline{25.2}$ & $\underline{12.5}$ & 6.3 & $\underline{23.8}$ \\
\hline $\mathrm{Bg}$ & 0.5 & & & 1.3 & & & 30 & & & 6.0 & & & 5.0 & & \\
\hline U-1 & 0.6 & 0.1 & 0.7 & 1.5 & 0.4 & 2.8 & $\underline{180}$ & 69 & $\underline{\mathbf{3 2 8}}$ & 7.1 & 1.9 & 11.3 & 5.7 & 1.7 & 8.2 \\
\hline U-3 & 0.7 & 0.1 & 0.8 & 3.6 & 2.8 & 10.0 & 85 & 40 & 141 & 13.1 & 6.0 & $\underline{26.0}$ & 9.4 & 4.0 & 14.8 \\
\hline U-5 & 0.5 & 0.4 & 1.0 & 6.5 & 6.8 & 24.4 & 130 & 53 & 198 & 13.5 & 5.2 & 24.2 & 28.6 & 9.1 & 39.5 \\
\hline
\end{tabular}

$A$ mean $(\mathrm{mg} / \mathrm{kg}), B$ standard deviation $(\mathrm{mg} / \mathrm{kg}), C$ maximum content $(\mathrm{mg} / \mathrm{kg}), B g$ geochemical background-mean content in three reference samples

The highest values for each site are in boldunderlined 

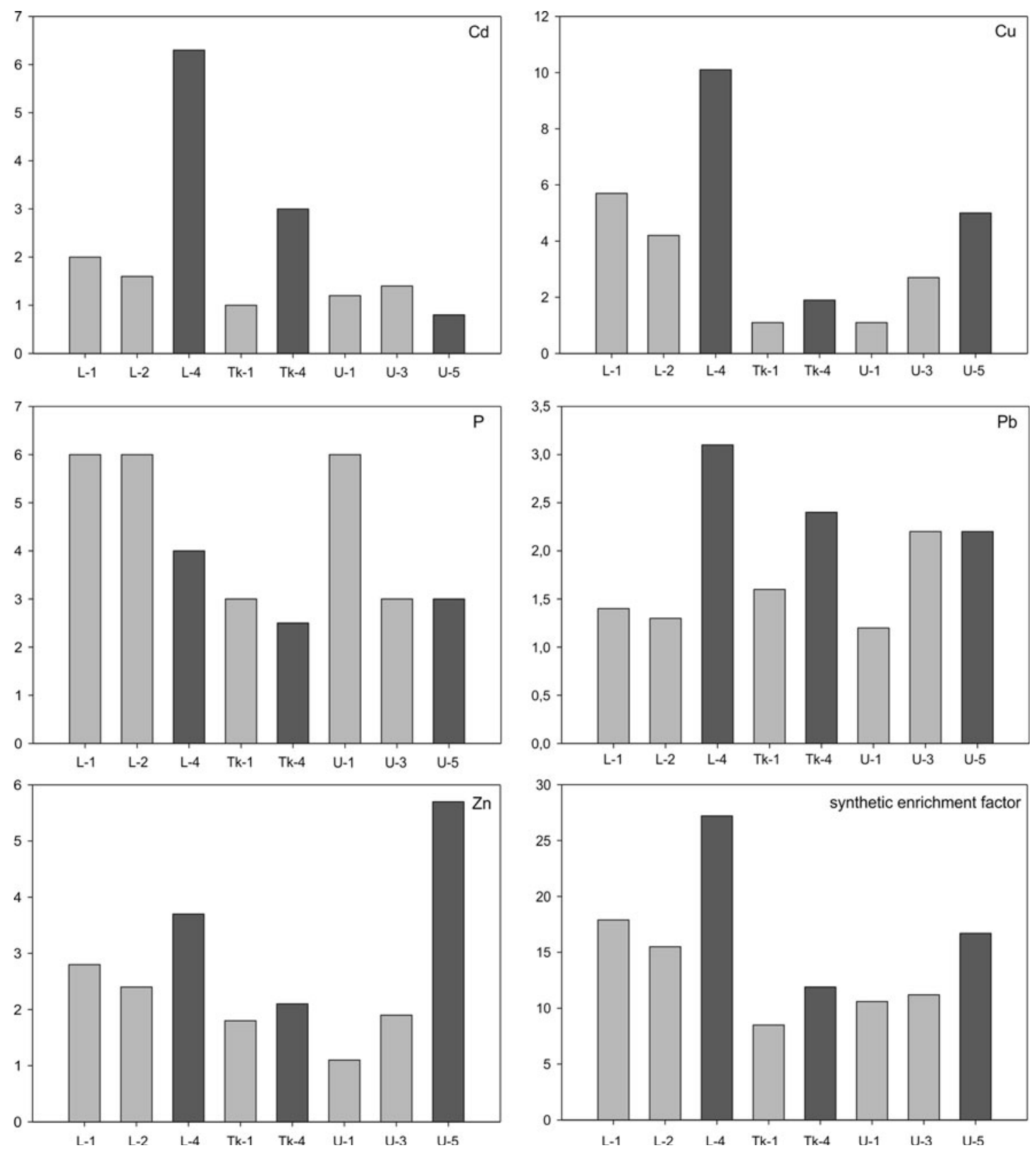

Fig. 2 Enrichment ratios in studied profiles (enrichment ratio = mean for the profile divided by the background value; the darker colour indicates profiles taken from depressions or foot-slope locations)

copper and lead recorded in the profile at the foot of the slope (Table 3). Similar patterns were found during studies conducted at the Neolithic site in Karmanowice-increased trace metal and phosphorus content did not occur within the site (Fig. 4).

In some profiles (Tk-4 or U-5, for example) higher concentrations of elements were observed in upper parts of soils profiles: $0-30 \mathrm{~cm}$ (Fig. 3). It could be a result of recent agriculture (fertilising, higher content of organic matter) or effect air contamination. In other profiles, this pattern did not occur and the surface layers did not show higher concentrations of studied elements. In the case of profiles of sediments filling closed depressions located within the Neolithic site in Karmanowice, the phosphorus enrichment of the deeper horizons was several times higher than in the present-day ploughing horizon (Fig. 5).

A greater vertical variation observed in profiles located within depressions results from changes in the character of the deposits and changes in element content in the eroded material (Fig. 3).

The duration of human settlement had an impact on the concentrations of the studied elements. The lowest content 

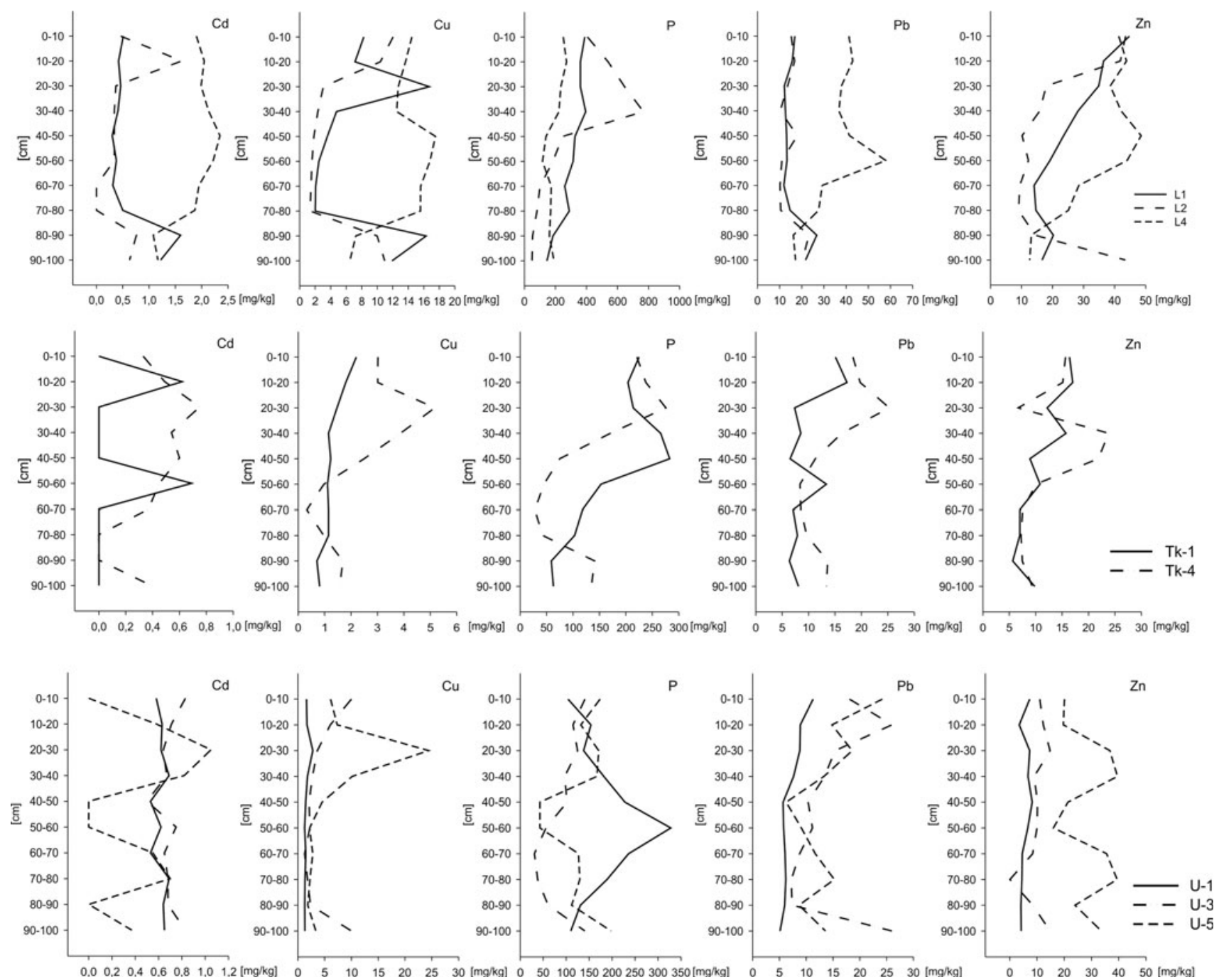

Fig. 3 Vertical distributions of $\mathrm{Cd}, \mathrm{Cu}, \mathrm{Pb}, \mathrm{P}$, and $\mathrm{Zn}$ concentrations in profiles in Łukawica, Ulów and Tarkawica sites
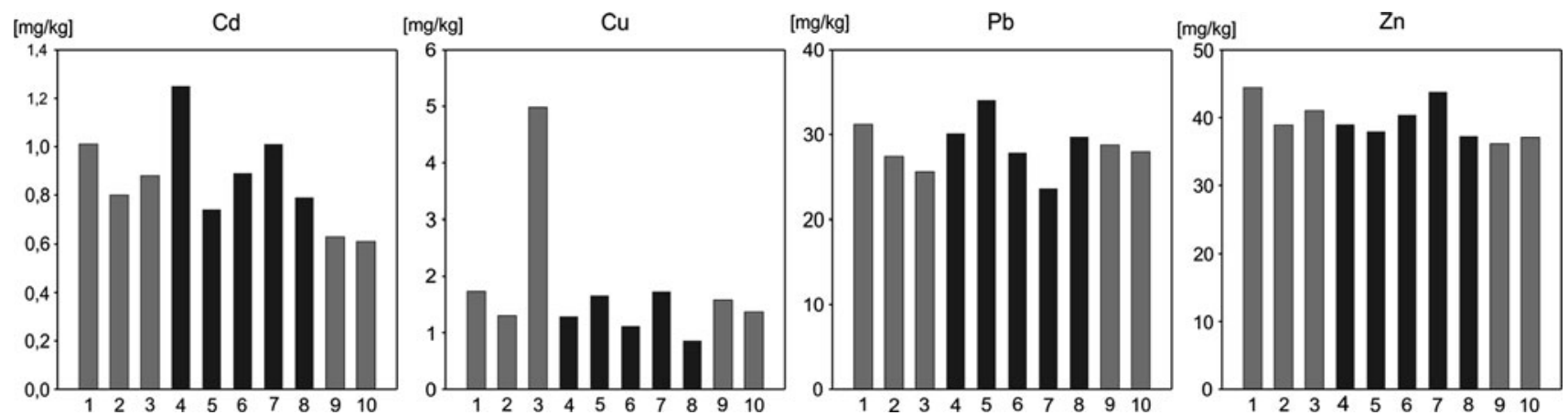

Fig. 4 Concentrations of trace metals within the surface layers in Karmanowice (dark colour indicates samples taken from the Neolithic site) (Zgłobicki, unpublished data)

occurred at Tarkawica (the shortest duration of settlement), and the highest at Łukawica (multicultural site). The indicators of the anthropogenic character of sediments proposed by Weng et al. (2003) also show an important role of human impact in the case of sediments filling the depressions within archaeological sites (Fig. 6).

Enrichment ratios (see Fig. 2; Table 3) are rather small compared to the values reported by other authors (Aston et al. 
Fig. 5 Vertical distribution of phosphorus concentrations in the profiles of sediments from Karmanowice (Neolithic site) (Zgłobicki, unpublished data)

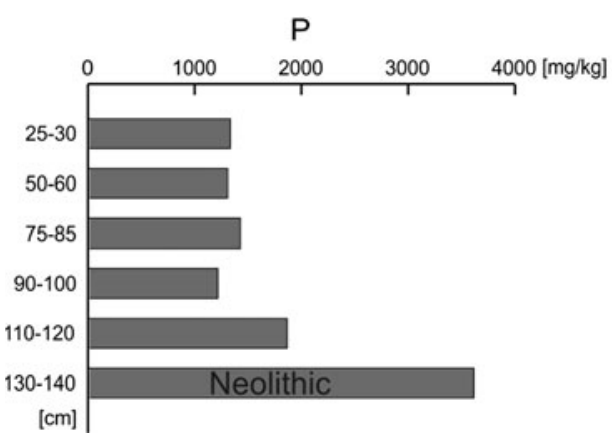

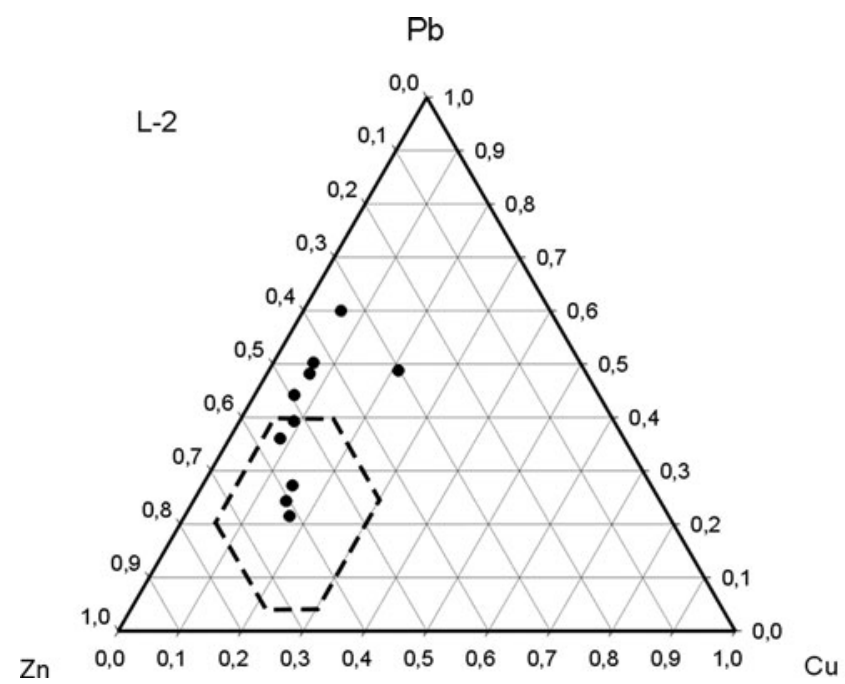

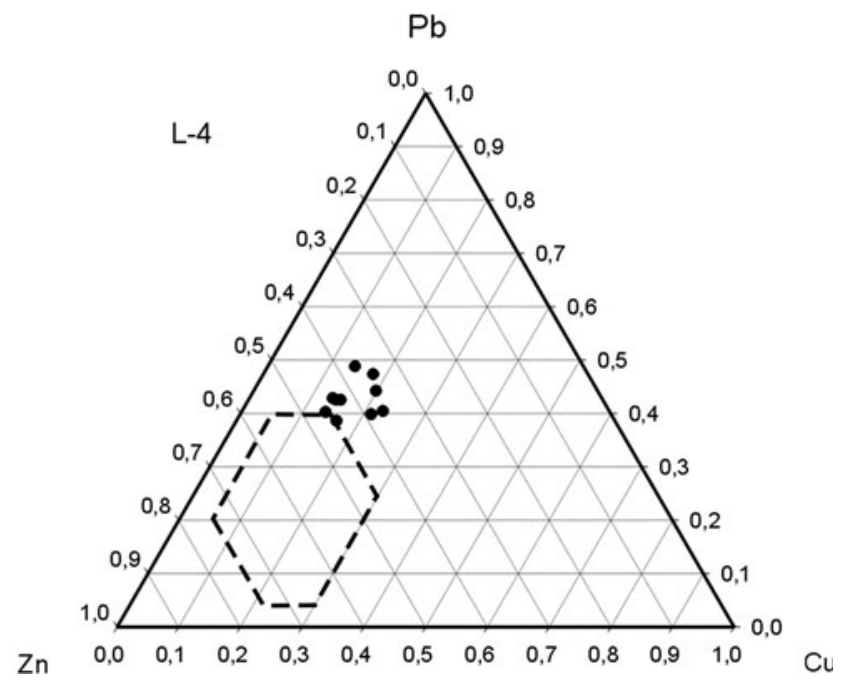

Fig. 6 Relations between contents of $\mathrm{Cu}, \mathrm{Pb}$ and $\mathrm{Zn}$ in the profiles of $\mathrm{L}-2$ and $\mathrm{L}-4$; values within the area surrounded by a dotted line are regarded as natural (after Weng et al. 2003)

1998; Entwisle et al. 2000; Schlezinger and Howes 2000; Wells et al. 2000; Parnell et al. 2002). Relatively low content values indicate that the elements, particularly phosphorus, have been partially washed out by the infiltrating water and overland flow. This results primarily from the low $\mathrm{pH}$, which is conducive to the migration of elements in solutions.

Colluvia forming within the archaeological sites thus constitute unique geoarchives where the history of human impact on the environment has been recorded. Geochemical analyses of sediments filling depressions and small valleys were also used in geomorphological studies to estimate the present-day landscape evolution and soil erosion intensity (Clemens and Stahr 1994; Gillijns et al. 2005; Dobrowolski et al. 2010; Augustinus et al. 2010; Nehyba et al. 2010; Zádorová et al. 2013).

\section{Conclusions}

- Increased trace metals and phosphorus content was found within the archaeological sites studied. Human impact was not limited to the surface layers, but also affected the deeper parts of the profiles. Enrichment factors were low due to soil parameters.

- The highest concentrations of the elements occurred at the bottoms of depressions and at the foot of slopes. In these profiles, the geochemical record of human activity was often more intensive than within the archaeological objects.

- Soil erosion can cause the removal of the upper parts of soil profiles, thus destroying the geochemical traces of archaeological sites. Eroded material is accumulated in the depressions and at foot-slope locations. As a result microtopography modifies the initial geochemical human impact within archaeological sites and makes it more spatially diversified. It should be taken into account when using geochemical prospecting.

- In order to examine the geochemical record of human activity within archaeological sites in areas with varied topography, one should start to look for it at the bottoms of depressions and at the foot of slopes.

Acknowledgments I wish to express my gratitude to Marcin Juściński, Barbara Niezabitowska-Wiśniewska and Marcin Piotrowski 
(Archaeological Institute, Maria Curie-Sklodowska University) for the help and useful discussions during sampling within the archaeological sites. I also acknowledge Andrzej Plak and Lesia Lata (Department of Soil Science, Maria Curie-Sklodowska University) who made the geochemical analysis. I want to thank anonymous reviewers for the valuable comments to improve the paper.

Open Access This article is distributed under the terms of the Creative Commons Attribution License which permits any use, distribution, and reproduction in any medium, provided the original author(s) and the source are credited.

\section{References}

Aston MA, Martin MH, Jackson AW (1998) The use of heavy metal soil analysis for archaeological surveying. Chemosphere 37: 465-477

Augustinus P, Barton CE, Zawadzki A, Harle K (2010) Lithological and geochemical record of mining-induced changes in sediments from Macquarie Harbour, southwest Tasmania, Australia. Environ Earth Sci 61:625-639. doi:10.1007/s12665-009-0377-x

Cabala J, Smieja-Król B, Jablonska M, Chrost L 2012. Mineral components in a peat deposit: looking for signs of early mining and smelting activities in Silesia-Cracow region (Southern Poland). Environ Earth Sci. doi:10.1007/s12665-012-2080-6

Clemens G, Stahr K (1994) Present and past soil erosion rates in catchments of the Kraichgau area (SW Germany). Catena 22: 153-168

Dobrowolski R, Ziółek M, Bałaga K, Melke J, Bogucki A (2010) Radiocarbon age and geochemistry of the infillings of small closed depressions from western polesie (Poland SE, Ukraine NW). Geochronometria 36:39-46. doi:10.2478/v10003-0100010-8

Entwisle JA, Doghson RA, Abrahams PW (2000) An investigation of former land-use activity through the physical and chemical analysis of soils from the isle of lewis, outer hebrides. Archaeol Prospect 7:171-188

Gillijns K, Poesen J, Deckers J (2005) On the characteristics and origin of closed depressions in loess-derived soils in Europecase study from the Central Belgium. Catena 60:43-58. doi: 10.1016/j.catena.2004.10.001

Kłosińska E, Juściński M (2001) Wstępne wyniki badań archeologicznych w Tarkawicy, stan. 5, pow. Lubartów, w latach 2001-2002. Archeologia Polski Środkowowschodniej 7:102-109

Lambert JB (1998) Traces of the past. Unravelling the secrets of archaeology through chemistry. Perseus Publishing, Cambridge

Lis J, Pasieczna A (1995) Atlas geochemiczny Polski 1:2 500000. Państwowy Instytut Geologiczny, Warszawa

Lutz HJ (1951) The concentration of certain chemical elements in the soils of Alaskan archeological sites. Am J Sci 249:925-928
Nehyba S, Hilscherová K, Jarkovský J, Dušek L, Kuchovský T, Zeman J, Klánová J, Holoubek I (2010) Grain size, geochemistry and organic pollutants in modern fluvial deposits in eastern Moravia (Czech Republic). Environ Earth Sci 60:591-602. doi: 10.1007/s12665-009-0199-x

Niezabitowska B (2005) Zanim przyszli Słowianie czyli Roztocze u schyłku starożytności. In: Banasiewicz-Szykuła E (ed) Archeologia Roztocza. Krajobraz przyrodniczo-kulturowy, Lublin, pp 73-101

Oonk S, Slomp CP, Huisman JD (2009) Geochemistry as an aid in archaeological prospection and site interpretation: current issues and research directions. Archaeol Prospect 16:35-51. doi: 10.1002/arp.344

Parnell JJ, Nelson Z, Terry RE (2002) Soil chemical analyses applied as an interpretive tool for ancient human activities in Piedras Negras, Guatemala. J Archaeol Sci 29:379-404. doi:10.1006/ jasc. 2002.0735

Schlezinger DR, Howes BL (2000) Organic phosphorus and elemental ratios as indicators of prehistoric human occupation. J Archeol Sci 27:479-492. doi:10.1006/jasc.1999.0464

Terry RE, Fernández FG, Parnell JJ, Inomata T (2004) The story in the floors: chemical signatures of ancient and modern Maya activities at Aguateca, Guatemala. J Archaeol Sci 31:1237-1250. doi:10.1016/j.jas.2004.03.017

Tian XS, Zhu Ch, Sun ZB, Shui T (2012) An evaluation of heavy metal pollution within historic cultural strata at a specialized salt production site at Zhongba in the Three Gorges Reservoir region of the Yangtze River, China. Environ Earth Sci. doi: 10.1007/ s12665-012-2042-Z

Szwarczewski P (2005) Geochemiczny i paleogeograficzny zapis dynamiki procesów rzeźbotwórczych w holocenie na przykładzie stoków w okolicach Płocka. In: Richling A, Lechnio J (eds) Z problematyki funkcjonowania krajobrazów nizinnych. WGiSR UW, Warszawa, pp 77-88

Wells EC, Terry RE, Parnell JJ, Hardin PJ, Jackson MW, Houston SD (2000) Chemical analyses of ancient anthrosols in residential areas at Pieda Negras, Guatemala. J Archaeol Sci 27:449-462. doi:10.1006/jasc. 1999.0490

Weng HX, Hang XM, Chen XH, Wu NY (2003) The stability of the relative content ratios of $\mathrm{Cu}, \mathrm{Pb}, \mathrm{Zn}$ in soils and sediment. Environ Geol 45:79-85. doi:10.1007/s00254-003-0859-1

Zádorová T, Penížek V, Šefrna L, Drábek O, Mihaljevič M, Volf S, Chuman T (2013) Identification of Neolithic to Modern erosionsedimentation phases using geochemical approach in a loess covered sub-catchment of South Moravia, Czech Republic. Geoderma 195-196:56-69. doi:10.1016/j.geoderma.2012.11.012

Zgłobicki W, Lata L, Plak A, Reszka M (2011) Geochemical and statistical approach to evaluate background concentrations of $\mathrm{Cd}$, $\mathrm{Cu}, \mathrm{Pb}$ and $\mathrm{Zn}$ (case study: Eastern Poland). Environ Earth Sci 62:347-355. doi:10.1007/s12665-010-0529-z

Zgłobicki W, Rodzik J (2007) Heavy metals in slope deposits of loess areas of the Lublin Upland (E Poland). Catena 71:84-95. doi: 10.1016/j.catena.2006.10.008 